\title{
Prey Availability or Electivity in the Diet of some Amphibians from Olinlin- Uzea, Esan North East, Edo State, Nigeria
}

\author{
Ogoanah, S. O. ${ }^{1, *}$ and Enomongale, M. E. ${ }^{1}$ \\ ${ }^{1}$ Department of Animal and Environmental Biology, University of Benin, Benin City, Nigeria \\ Corresponding Author:*sylvia.ogoanah@uniben.edu
}

\begin{abstract}
The diet of four species of frogs, Hoplobatrachus occipitalis, Ptychadena bibroni, Amietophrynus maculatus and Leptopelis sp. from Olinlin -Uzea, Esan North East Local Government Area in Edo State, Nigeria was studied between July and November 2014. Specimens were stomach-flushed and a total of 166 prey items from 13 prey categories recorded. Hoplobatrachus occipitalis had the highest niche breadth (6.04) indicating a rich diversity of prey while Leptopelis sp. an arboreal frog had the least (2.67). Hoplobatrachus occipitalis and P. bibroni had a niche overlap of 0.79 indicating a common use of the microhabitat while no overlap was recorded between Leptopelis sp. and Amietophrynus maculatus and P. bibroni. The low electivity indices observed in Hoplobatrachus occipitalis, Ptychadena bibroni, and Amietophrynus maculatus is an indication that feeding was based more on the availability of prey rather than preference. Although a high electivity index was recorded for Leptopelis sp, it is most likely due to its restricted microhabitat and the corresponding available prey. Caution should, however, be employed with electivity indices as results could be affected by inadequate sampling.
\end{abstract}

Keywords: Diet, prey availability, electivity, niche breadth, niche overlap, anurans

\subsection{Introduction}

Amphibians have often been thought of as generalist or opportunistic feeders, feeding mainly on insects. Although diet studies in amphibians date as far back as Toft (1980) few studies have however been done to determine if the diet was based on prey availability or electivity. In one of such works, Junca and Eterovick (2007) suggested stability either in prey availability or food selection in Anomaloglossus stepheni due to the similar diet composition between populations in different time zones. In a similar work, although electivity index showed Hypsiboas punctatus to forage more on dipterans slightly above the environmental abundance which would have placed it as a specialist feeder, resource availability data however placed it as a generalist feeder feeding more on the main food item and other secondary prey based on their resource availability (Lopez et al., 2009). It is thus important to have an idea of the resource availability when making interpretations from diet analysis.

Thus, a knowledge of amphibian species diet and deductions from its interwoven nature and relationships is needed more than ever before in ecological studies for a better understanding of their feeding ecology. More recent works on prey electivity by Costa et al. (2014) showed contradictory results in prey ingested based on the method of analysis with stomach flushing method more preferred to faecal analysis method as most soft-bodied prey get digested in the stomach without traces of it in the faecal content giving a false information on prey selectivity. Electivity values should, however, be used with care as it has been shown that inadequate sampling of the environment for prey could lead to high electivity values which do not give a true picture of the diet preferences of the particular species being studied. Flowers and Graves (1995), Caldert et al. (2012). This work was undertaken to determine if the diet of the four anurans under study is based on prey availability or electivity. 


\subsection{Materials and Methods}

This study was undertaken at Olinlin-Uzea, in Esan North East Local Government Area of Edo State during the rainy season. The area is characterised by dense forest trees and a river located within a depression. The nearest human habitation is about 800metres away.

\subsection{Stomach Flushing and Statistical Analyses}

Stomach flushing as described by Legler and Sullivan (1979) was done on the amphibians immediately after capture. Preys were sorted from the collected stomach contents using the sorting microscope in the laboratory. Each prey sample collected was identified to the lowest taxonomic level possible; usually, this was to the order level. Slightly disarticulated prey and non-insect prey were also identified to the order level of taxonomy using a dichotomous key (Gillot, 2005).

Statistical Analysis:

$$
\text { Frequency of occurrence }=\frac{\text { Number of stomachs with particular prey }}{\text { Total number of stomachs with prey }}
$$

In the same vein, the percentage abundance of each prey item was obtained by percentage analysis of the above formula as:

$$
\text { Percentage abundance of each prey item }=\frac{\text { Number of a particular prey }}{\text { Total number of prey }} \times 100 \%
$$

The Shannon index, often referred to as the Shannon-Wiener index, (Magurran, 1988) is a richness measure that takes into account the proportional abundances of each prey item found in the frogs was calculated with the equation:

$$
\mathrm{H}=-\Sigma \mathrm{P}_{\mathrm{i}} \ln \mathrm{P}_{\mathrm{i}}
$$

Where: $P_{i}$, is the proportional abundance of the ith species which is given by $\left(n_{i} / N\right)$, where $n_{i}$ is the number of individuals of the particular species while $\mathrm{N}$ is the total number of frogs caught and examined.

The percentage abundance of frog species was determined by the percentage estimation of the ratio of frogs that belong to the same species to the total number of frogs caught.

$$
\text { Percentage number of frogs caught }=\frac{\text { Number of frogs of same species }}{\text { Total number of frogs }} \times 100 \%
$$

The significance of the variation in the percentage number of frogs caught was analyzed using the analysis of variance (ANOVA).

Trophic niche overlaps between two species in permutated order were obtained using the index developed by May and MacArthur (1972) and Pianka (1974).

An ecological niche overlap ranges in value from 0 (which indicates no overlap - no resource used in common) to 1 (which indicates a complete overlap). The ecological niche breadth (Krebs, 1999) was calculated by using Levins measure (1968) which measures how uniformly resources are being utilized by each species. It is also called niche width or niche size (Colwell and Futuyma, 1971). The equation is given by:

$$
\frac{B}{\sum P_{i}^{2}}=1
$$

Where $\mathrm{B}$ is the Levins measure of niche breadth and $\mathrm{p}_{\mathrm{i}}$ is the proportion of individuals found using the resource, $\mathrm{i}$. 


\subsection{Results and Discussion}

A total of 51 frog specimens consisting of 4 species namely, Hoplobatrachus occipitalis (41.2\%), Ptychadena bibroni (35.3\%), Amietophrynus maculatus (21.6\%) and Leptopelis spp. (1.96) were stomach flushed during the period of study from July to November 2014. The total number of prey items collected from the frogs was 166.

The prey items found in the environment and those in the stomach of the frogs, their respective number of occurrence, frequency and relative frequency of each prey are shown in Table 1 while the ecological niche overlaps are shown in Table 2. The total number of prey items collected from Hoplobatrachus occipitalis was 73 with a niche breadth of 6.04. The Shannon-Wiener species diversity index $(\mathrm{H})$ was 0.365 ( $\mathrm{p}<0.05)$. The preys consisted of various orders of insects and some other groups of organisms expressed in percentage composition of diet: Hymenoptera (26.03\%), Isoptera (16.44\%), Arachnida (13.7\%), Diptera (8.22\%), Lepidoptera (8.22\%), Plant parts $(8.22 \%)$ and a mammal $(1.37 \%)$. Unidentifiable prey items constituted $17.81 \%$ of the preys.

The total number of prey items collected from Ptychadena bibroni was 59 with a niche breadth of 5.3. The Shannon-Wiener species diversity index $(\mathrm{H})$ was $0.368(\mathrm{p}<0.05)$. The prey composition was made up of several orders of insects expressed in percentage composition of diet (Figure 5): Hymenoptera (30.51\%), Coleoptera (18.64\%), Isoptera (13.56\%), Diptera (10.17\%), Myriapoda (3.39\%), Arachnida (3.39\%), Annelida (1.7\%) unidentifiable prey items (16.95\%) and empty stomach (1.69\%).

The prey items found in Amietophrynus maculatus were 30 in number. The food was composed of several groups of invertebrates expressed in percentage abundance: Hymenopterans (16.7\%), Isopterans (30\%), Coleopterans (16.7\%), Dipterans (20\%), Diplopod (6.7\%), unidentifiable prey items (6.7\%) and empty stomach (3.3\%). The high percentage of unidentified preys was due to excess disarticulation of prey body parts. Ecological niche breadth was 5.11 and $(\mathrm{H})=0.331$.

Leptopelis sp. had 4 preys with a niche breadth of 2.67 and $(\mathrm{H})=0.075$. The food consisted of Orthoptera, Lepidoptera and some unidentifiable prey items. This was also due to excess disarticulation of prey body parts.

Leptopelis had the highest electivity values of 0.93 for Orthoptera and 0.84 for Lepidoptera while Hoplobatrachus occipitalis had an electivity index of 0.76 for Arachnida.

Table 1: Prey Categories Consumed by H. occipitalis, P. bibroni, A. maculatus, and Leptopelis sp. from Olinlin -Uzea, Edo State.

\begin{tabular}{|c|c|c|c|c|c|c|c|c|c|c|c|c|c|c|c|c|c|}
\hline \multirow{2}{*}{$\begin{array}{l}\text { Preys found } \\
\text { in the } \\
\text { environment }\end{array}$} & \multirow{2}{*}{$\begin{array}{l}\text { Preys found in } \\
\text { frog stomach }\end{array}$} & \multicolumn{4}{|c|}{ Hoplobatrachus occipitalis } & \multicolumn{4}{|c|}{ Ptychadena bibroni } & \multicolumn{4}{|c|}{ Amietophrynus maculatus } & \multicolumn{4}{|c|}{ Leptopelis sp } \\
\hline & & $\mathbf{N}$ & $\mathrm{N} \%$ & $\mathbf{F}$ & $\mathbf{F} \%$ & $\mathbf{N}$ & $\mathrm{N} \%$ & $\mathbf{F}$ & $\mathrm{F} \%$ & $\mathbf{N}$ & N\% & $\mathrm{F}$ & $\mathrm{F} \%$ & $\mathbf{N}$ & $\mathrm{N} \%$ & $\mathbf{F}$ & $\mathrm{F} \%$ \\
\hline Lepidoptera & Lepidoptera & 6 & 8.2192 & 5 & 7.6923077 & 0 & 0 & 0 & 0 & 0 & 0 & 0 & 0 & 1 & 25 & 1 & 25 \\
\hline Isoptera & Isoptera & 12 & 16.438 & 10 & 15.384615 & 8 & 13.559 & 6 & 11.32075 & 9 & 30 & 7 & 26.92308 & 0 & 0 & 0 & 0 \\
\hline Hymenoptera & Hymenoptera & 19 & 26.027 & 17 & 26.153845 & 18 & 30.508 & 16 & 30.18868 & 5 & 16.667 & 5 & 19.23077 & 0 & 0 & 0 & 0 \\
\hline Diptera & Diptera & 6 & 8.2192 & 6 & 9.2307692 & 6 & 10.169 & 5 & 9.433962 & 6 & 20 & 5 & 19.23077 & 0 & 0 & 0 & 0 \\
\hline $\begin{array}{l}\text { Orthoptera } \\
\text { Dictyoptera }\end{array}$ & Orthoptera & 0 & 0 & 0 & 0 & 0 & 0 & 0 & 0 & 0 & 0 & 0 & 0 & 1 & 25 & 1 & 25 \\
\hline $\begin{array}{l}\text { Coleoptera } \\
\text { Odonata }\end{array}$ & Coleoptera & 0 & 0 & 0 & 0 & 11 & 18.644 & 10 & 18.86792 & 5 & 16.667 & 4 & 15.38462 & 0 & 0 & 0 & 0 \\
\hline Arachnida & Arachnida & 10 & 13.699 & 9 & 13.846154 & 2 & 3.3898 & 2 & 3.773585 & 0 & 0 & 0 & 0 & 0 & 0 & 0 & 0 \\
\hline $\begin{array}{l}\text { Diplopoda } \\
\text { Fish }\end{array}$ & Diplopoda & 0 & 0 & 0 & 0 & 0 & 0 & 0 & 0 & 2 & 6.6667 & 2 & 7.692308 & 0 & 0 & 0 & 0 \\
\hline $\begin{array}{l}\text { Myriapoda } \\
\text { Mollusca }\end{array}$ & Myriapoda & 0 & 0 & 0 & 0 & 2 & 3.3898 & 2 & 3.773585 & 0 & 0 & 0 & 0 & 0 & 0 & 0 & 0 \\
\hline Annelida & Annelida & 0 & 0 & 0 & 0 & 1 & 1.6949 & 1 & 1.886792 & 0 & 0 & 0 & 0 & 0 & 0 & 0 & 0 \\
\hline Mammal & Mammal & 1 & 1.3699 & 1 & 1.5384615 & 0 & 0 & 0 & 0 & 0 & 0 & 0 & 0 & 0 & 0 & 0 & 0 \\
\hline & Empty stomach & 0 & 0 & 0 & 0 & 1 & 1.6949 & 1 & 1.886792 & 1 & 3.3333 & 1 & 3.846154 & 0 & 0 & 0 & 0 \\
\hline & Unknown & 13 & 17.808 & 13 & 20 & 10 & 16.949 & 10 & 18.86792 & 2 & 6.6667 & 2 & 7.692308 & 2 & 50 & 2 & 50 \\
\hline & Plants Parts & 6 & 8.2192 & 4 & 6.1538462 & & & & & & & & & & & & \\
\hline
\end{tabular}

Where $\mathrm{F}=$ total frequency, $\% \mathrm{~F}=$ relative frequency; $\mathrm{N}=$ total abundance and $\% \mathrm{~N}=$ relative abundance 
Table 2: The niche overlap of the four Anuran species

\begin{tabular}{lcc}
\hline Species Pairs & Niche Overlap & Percentage Overlap \\
\hline H. occipitalis and P. bibroni & 0.787 & 31.04 \\
H. occipitalis and A. maculatus & 0.69 & 27.22 \\
H. occipitalis and Leptopelis sp. & 0.225 & 8.88 \\
P. bibroni and A. maculatus & 0.833 & 32.86 \\
P. bibroni and Leptopelis sp. & 0.0 & 0.0 \\
A. maculatus and Leptopelis sp. & 0.0 & 0.0 \\
\hline
\end{tabular}

The highest niche overlap of 0.83 was recorded between Ptychadena bibroni and Amietophrynus maculatus which are both terrestrial frogs and they were observed foraging together. Leptopelis sp which is a treefrog had a low niche overlap of 0.23 with $H$. occipitalis and none at all with P. bibroni and A. maculatus. This clearly places Leptopelis, a tree frog in its own micro habitat as it feeds from treetops occasionally coming to the forest floor to forage.

The high niche overlap observed between Ptychadena bibroni and Hoplobatrachus occipitalis could be due to the common environment they share. Although $H$. occipitalis is completely aquatic, it is sometimes seen on the banks of water bodies only to dive into water when disturbed. Ptychadena bibroni on the other hand seen mainly around the banks of pools and around grasses also leaps into the water to escape from predators. This intertwining of their microhabitat would thus mean getting prey from the same source.

Niche breadth which shows the diversity of prey items consumed by a frog was seen to be in the order H. occipitalis $>P$. bibroni $>$ A. maculatus $>$ Leptopelis. This correlates with the fact that $H$. occipitalis feeds from two habitats- aquatic and terrestrial thus having a wider prey diversity while Leptopelis is somewhat restricted in its arboreal habitat feeding mainly at the treetops, and sometimes forest floor, hence its low niche breadth.

H. occipitalis has been shown to be a generalist feeder - feeding on anything that moves and can fit into its mouth (Hirschfeld and Rodel, 2011). There does not seem to be a constant food in its diet. There were about seven prey categories and plant parts which indicate an intense feeding based on the availability of a rich trophic base. It feeds mainly on insects which are the normally known food of frogs but also consumes other groups of prey which include arachnids and a mammal (a mouse). It is therefore understandable that Hymenopterans had the highest percentage frequency of occurrence of 26.03\%. There were also seven prey categories observed in Ptychadena bibroni and like Hoplobatrachus occipitalis, the insect order Hymenoptera had the highest percentage consumption (30.51\%). Ferreira et al. (2015) reported the greenhouse frog having preference for Hymenopterans in nine out of ten sites sampled in Maui, Hawaii, with consumption even higher than was available in the environment and an electivity index that ranged between 0.90 and 0.99. Specimens of myriapod (centipede), arachnid (spider) and annelid (earthworm) also constitute part of the frog's diet. This shows the diversity of prey selection in Ptychadena bibroni and they could also be regarded as opportunistic feeders.

The single specimen of Leptopelis species collected was the only frog with grasshoppers (Orthoptera) in its diet. One common observation for each of the terrestrial species of frogs was the occurrence of a common collection of prey items. Examples include Hymenopterans, Isopterans and Dipterans which occurred in three species Hoplobatrachus occipitalis, Ptychadena bibroni and Amietophrynus maculatus. It was observed that Amietophrynus maculatus had more of Isopterans in its diet than Hymenoptera as is usually observed in most amphibians. This could be due to prey availability rather than preference as most researchers have shown amphibian diet to be based more on available resources than prey selectivity (Labanick, 1976; MacNamara 1977, Duelman and Trueb 1994). 


\subsection{Conclusion}

The low electivity indices recorded for the species indicates that they are generally opportunistic feeders depending more on prey availability than on preference. Kovacs et. al (2007) also observed that frogs tend to make use of available prey within their environment. The high electivity index of Leptopelis sp. could be due more to the availability of the insects in its arboreal habitat than its preference for them. Electivity indices could thus also be used for demarcating amphibians into their microhabitats.

\section{References}

Caldert, V. M., Samanta, L., Bertaso, T.B.R. and Cechin, S. Z. (2012). Feeding Ecology of Crossodactylus schmidti (Anura: Hylodidae) in Southern Brazil. Zoological Studies 51: 484-493.

Costa, A., Salvidio, S., Posillico, M., Altea, T., Matteucci, G. and A. Romano (2014). What goes in does not come out: Different non-lethal dietary methods give contradictory interpretation of prey selectivity in amphibians. Amphibia-Reptilia 35 (2): 255-262

Duellman, W.E and Trueb, L. (1994). Biology of Amphibians. John Hopkins University Press. Baltimore. 670pp

Flowers, M.A. and Graves, B.M. (1995). Prey selectivity and size specific diet changes in Bufo cognatus and Bufo woodhousi during early post metamorphic ontogeny. J. Herpetol. 29: 608-612

Gillot, C. (2005). Entomology (3rd ed.). Springer Publishers 834pp.

Hirschfeld, M. and Rodel, M. O. (2011). The diet of the African Tiger frog, Hoplobatrachus occipitalis in Northern Benin. Salamandra 47: 125-132.

Junca, F.A, and Eterovick, P.C. (2007). Feeding ecology of two sympatric species of Aromobatidae, Allobates marchesianus and Anomaglossus stepheni in Central Amazon. Journal of Herpetology 41: $296-303$

Kovacs, E. H., Sas, I., Covaciu-Marcov, S. D., Hartel, T., Cupsa, D. and Groza, M. (2007). Seasonal variation in the diet of a population of Hyla arborea from Romania. Amphibia-Reptilia 28: 485-491.

Labanick, G.M. (1976). Prey availability, consumption and selection in the cricket frog Acris crepitans (Amphibia, Anura, Hylidae.) Journal of Herpetology 10: 293-298

Legler, J. M., and Sullivan, L. J. (1979). The application of stomach-flushing to lizards and anurans. Herpetologica 35: 107-110.

Lopez, J. A., Scarabotti, P.A., Medrano, M. C. and Ghirardi, R. (2009). Is the red spotted green frog Hypsiboas punctatus (Anura: Hylidae) selecting its preys? The importance of prey availability. Rev.biol trop 57(3): 847-857

MacNamara, M.C. (1977). Food habits of terrestrial adult migrants and immature red efts of the redspotted newt Notophthalmus viridescens. Herpetologia 33:127 - 132

Magurran, A. E. (1988). Ecological Diversity and Its Measurement. Princeton University Press, Princeton, New Jersey.179pp.

May, R. M. and MacArthur, R. H. (1972). Niche Overlap as a function of environmental variability. Proceedings of the National Academy of Science, USA 69: 1109-1113. 
Ogoanah, O. S. and Uchedike, E. (2011). Diet and feeding behaviour of the edible frog Hoplobatrachus occipitalis (Amphibia: Anura). African Scientist 12: 209-213.

Pianka, E. R. (1974). Niche overlap and diffuse competition. Proceedings of the National Academy of Science, USA 71: 2141-2145.

Toft, C.A. (1980). Feeding ecology of thirteen syntopic species of anurans in a seasonal tropical environment. Oecologia 45: 131-141. 